\title{
Liver nitrogen movements during short-term infusion of high levels of ammonia into the mesenteric vein of sheep
}

\author{
G. D. Milano ${ }^{1}$ and G. E. Lobley ${ }^{2}$ \\ ${ }^{1}$ Facultad de Ciencias Veterinarias, Universidad Nacional del Centro, Campus Universitario (7000) Tandil, Argentina \\ ${ }^{2}$ Rowett Research Institute, Greenburn Road, Bucksburn, Aberdeen AB21 9SB, Scotland, UK
}

(Received 3 April 2000 - Revised 17 April 2001 - Accepted 23 May 2001)

\begin{abstract}
Four $40 \mathrm{~kg}$ wethers were used in a crossover design to quantify, by arterio-venous procedures, the mass transfer of $\mathrm{NH}_{3}$, urea and amino acids (AAs) across the portal-drained viscera and the liver during a $31 \mathrm{~min}$ infusion of either $0(\mathrm{C} 0)$ or $1100(\mathrm{C} 1100) \mu \mathrm{mol} \mathrm{NH}_{4} \mathrm{HCO}_{3} / \mathrm{min}$ into the mesenteric vein. In $\mathrm{C} 1100$, hepatic $\mathrm{NH}_{3}$ extraction remained stable at $1214 \mu \mathrm{mol} / \mathrm{min}$ $\left(1.90 \mu \mathrm{mol} / \mathrm{min}\right.$ per $\mathrm{g}$ wet liver weight), the capacity for hepatic $\mathrm{NH}_{3}$ removal was exceeded by $654 \mu \mathrm{mol} / \mathrm{min}(P<0.05)$ and the incremental $(\mathrm{C} 1100-\mathrm{C} 0)$ urea-N release: $\mathrm{NH}_{3}-\mathrm{N}$ removal ratio increased progressively, from 0.52 to 0.90 . The $\mathrm{NH}_{4} \mathrm{HCO}_{3}$ infusion reduced total branchedchain AA $(P<0 \cdot 05)$ transfer across the portal-drained viscera and total AA-N $(P=0.09)$ and lysine $(P=0.02)$ extraction by the liver. Hepatic release of glutamate was augmented $(P=0.03)$, ornithine switched from net release to net removal $(P<0.001)$ and net splanchnic release of free essential AA (44 $\mu \mathrm{mol} / \mathrm{min}$ (SED 9.2), $P=0.04$ ) and branched-chain AA $(33 \mu \mathrm{mol} / \mathrm{min}$ (SED 2.0), $P=0.001$ ) were reduced to 0.58 of their basal rate. The study showed that conversion of excess $\mathrm{NH}_{3}$ to urea during a short-term hepatic $\mathrm{NH}_{3}$ overload required no additional contribution of AA-N to ureagenesis; essential AA and branched-chain AA supply to non-splanchnic tissues was, however, temporarily decreased.
\end{abstract}

Liver: Ammonia: Ureagenesis: Amino acids: Sheep

Large quantities of $\mathrm{NH}_{3}$ are formed in the gastrointestinal tract of ruminant animals from the degradation of dietary nitrogenous compounds and the microbial hydrolysis of endogenous urea. Once absorbed across the gut wall, the $\mathrm{NH}_{3}$ is completely removed from the splanchnic circulation by the liver (Nieto et al. 1996) and used for urea and, to a lesser extent, amino acid (AA) synthesis (e.g. glutamate, aspartate and glutamine; Lobley et al. 1996).

The role of hepatic ureagenesis in $\mathrm{N}$ metabolism is twofold: prevention of portal $\mathrm{NH}_{3}$ from reaching the peripheral circulation and disposal of the AA-N excess to body requirements. Urea synthesis requires balanced $\mathrm{N}$ inputs from citrulline and aspartate. Citrulline- $\mathrm{N}$ originates from mitochondrial $\mathrm{NH}_{3}$ in a reaction catalysed, sequentially, by carbamoyl-phosphate synthase 1 and ornithine transcarbamylase. The aspartate-N, supplied primarily through transamination with glutamate, arises mainly from two sources: (1) the 2-amino-N of transaminating AAs; or (2) direct synthesis of glutamate from mitochondrial $\mathrm{NH}_{3}$ and 2-oxoglutarate, via the reaction controlled by glutamate dehydrogenase (Stryer, 1988). $\mathrm{NH}_{3}-\mathrm{N}$ can, therefore, provide both $\mathrm{N}$ atoms of urea, as demonstrated in cultures of sheep hepatocytes incubated with ${ }^{15} \mathrm{NH}_{4} \mathrm{Cl}$ where, regardless of the presence of $\mathrm{AA}$ in the incubation medium, $\left[{ }^{15} \mathrm{~N}^{15} \mathrm{~N}\right]$ urea was the predominant labelled species synthesised (Lomax et al. 1995; Luo et al. 1995). Thus, hepatic detoxification of absorbed $\mathrm{NH}_{3}$, which can account for up to $0 \cdot 5-0.65$ of dietary $\mathrm{N}$ intake (Parker et al. 1995), may not need an obligate equimolar N input from AA (Reynolds, 1992; Parker et al. 1995).

This view is not supported by results from short-term $(2-3 \mathrm{~h})$, trans-hepatic experiments in vivo, where the urea$\mathrm{N}$ released by the liver greatly exceeded the additional $\mathrm{NH}_{3}$ supplied to the liver (Symonds et al. 1981; Barej et al. 1987; Orzechowsky et al. 1988; Wilton et al. 1988). If transient, high inputs of $\mathrm{NH}_{3}$ stimulate AA utilisation for ureagenesis, daily access to feedstuffs with high concentrations of non-protein- $\mathrm{N}$ or rapidly degradable protein-N for short periods may reduce AA availability for protein anabolism.

\footnotetext{
Abbreviations: AA, amino acid; PDV, portal-drained viscera.

* Corresponding author: Guillermo D. Milano, fax +54 2293 422667, email gmilano@vet.unicen.edu.ar
} 
In the current experiment, the hypothesis that a large, short-term increase in portal $\mathrm{NH}_{3}$ flow augments AA utilisation for urea synthesis was tested by increasing the supply of $\mathrm{NH}_{3}$ beyond the maximum capacity for hepatic $\mathrm{NH}_{3}$ by infusion of $1100 \mu \mathrm{mol} \mathrm{NH}_{4} \mathrm{HCO}_{3} / \mathrm{min}$ into the mesenteric vein of fed sheep.

\section{Materials and methods}

\section{Animals}

Four Suffolk cross-bred male lambs $(35-40 \mathrm{~kg}$ body weight), surgically prepared with indwelling silicone rubber catheters in the posterior aorta, portal, hepatic and mesenteric veins (Lobley et al. 1995), were placed in metabolism crates under continuous lighting conditions. The sheep were adjusted to receiving $770 \mathrm{~g}$ DM (grass pellets)/d (10 MJ metabolizable energy $/ \mathrm{kg} \mathrm{DM}, 22 \mathrm{~g} \mathrm{~N} / \mathrm{kg}$ $\mathrm{DM}$ ) in hourly portions throughout the experiment and for at least $10 \mathrm{~d}$ before the first experimental period, using automated feeders. Water was freely available.

\section{Design}

The experiment was arranged as a non-randomised, crossover design with two experimental periods, each of $161 \mathrm{~min}$, separated by a 5-7d interval. Throughout each experimental period, the sheep were infused via the mesenteric vein with a solution containing $0 \cdot 1 \mathrm{M}$ sodium $p$-amino hippuric acid (Sigma, St Louis, MO, USA), 0.05 M-sodium phosphate buffer ( $\mathrm{pH}$ 7.4) and $400 \mathrm{IU}$ heparin/g (Heparin (Mucous); Leo Laboratories Ltd, Princes Risborough, Bucks., UK), at a rate of $20 \mathrm{~g} / \mathrm{h}$. Between 60 and $130 \mathrm{~min}$ of each experimental period, the sheep were infused with physiological saline (152 mM-NaCl, $167 \cdot 2 \mu \mathrm{mol} \mathrm{NaCl} / \mathrm{min})$ via the mesenteric vein. From $130 \mathrm{~min}$ to the end of each experimental period, the infusion of physiological saline via the mesenteric vein was either maintained (C0) or replaced by a $1 \mathrm{M}-\mathrm{NH}_{4} \mathrm{HCO}_{3}$, $152 \mathrm{~mm}-\mathrm{NaCl}$ solution $\left(\mathrm{C} 1100 ; 1100 \mu \mathrm{mol} \mathrm{NH} \mathrm{NHCO}_{3} / \mathrm{min}\right.$ plus $167 \cdot 2 \mu \mathrm{mol} \mathrm{NaCl} / \mathrm{min})$. Two sheep followed the sequence $\mathrm{C} 0-\mathrm{C} 1100$ while the other two sheep followed the reverse sequence. All solutions were sterilised by autoclave or filtration, as appropriate, and infusions were performed with peristaltic pumps.

\section{Samples}

Three simultaneous blood samples were continuously collected (Lobley et al. 1995) from the aorta, portal and hepatic veins at $7 \mathrm{~min}$ intervals $(0.3 \mathrm{ml} / \mathrm{min}$ per catheter $)$, during the last $21 \mathrm{~min}$ of each experimental period, using a peristaltic pump. An additional mixed blood sample $(10 \mathrm{ml})$ was collected at the end of each experimental period for determination of blood and plasma DM.

Immediately following the study (2 weeks), portal catheter patency was lost in two of the sheep. This meant they could not be used for subsequent studies and were therefore killed. As they had been maintained postexperiment on the same diet and intake, the opportunity was taken to examine liver mass. This enabled the absolute measurements obtained to be expressed per unit weight. The sheep were weighed and then killed by an intravenous overdose of thiopental, followed by exsanguination. The liver was rapidly separated from other abdominal organs and surrounding connective and adipose tissue and weighed.

\section{Analyses}

Blood samples were mixed and analysed for blood $p \mathrm{CO}_{2}$, $\mathrm{pH}$, bicarbonate and haemoglobin concentration immediately after collection using a blood gas analyser (Acid Base Laboratory Radiometer ABL3; Radiometer, Copenhagen, Denmark). The packed cell volume was determined by microhaematocrit. One portion $(0.5 \mathrm{~g})$ of blood was deproteinised with $5 \mathrm{~g}$ TCA $(120 \mathrm{~g} / \mathrm{l})$ and processed for gravimetric determination of $p$-amino hippuric acid (Lobley et al. 1995). The remainder of the blood was centrifuged at $1000 \mathrm{~g}$ for $10 \mathrm{~min}$ at $4^{\circ} \mathrm{C}$, the plasma (approximately $1.0 \mathrm{ml}$ ) collected and processed for determination of $\mathrm{NH}_{3}$, by an automated procedure (Kone Autoanalyser; Kone, Espoo, Finland) according to Mondzac et al. (1965), and urea, by GC-mass spectrometry (Milano et al. 2000). The three arterial, portal and hepatic vein plasma samples from each experimental period were pooled in proportion to the plasma flow (pooled sample weight, approximately $0.5 \mathrm{~g}$ ), and processed for AA analysis in physiological fluids with an Alpha Plus amino acid analyser (Pharmacia-LKB Biochrom Ltd, Cambridge, UK) as described by Lobley et al. (1995).

\section{Calculations}

Blood, plasma and whole blood water flows and $\mathrm{NH}_{3}$, urea and AA transfers across the portal-drained viscera (PDV) and the liver were calculated as described by Milano et al. (2000). Hepatic $\mathrm{NH}_{3}$ and urea-N inflow $(I, \mu \mathrm{mol} / \mathrm{min})$ and outflow $(O, \mu \mathrm{mol} / \mathrm{min})$ were calculated from:

$$
I=F p C p+(F h-F p) C a,
$$

and

$$
O=F h C h,
$$

where $\mathrm{Fp}$ and $\mathrm{Fh}$ are the blood (for $\mathrm{NH}_{3}$ ) or whole blood water (for urea) flow in the portal vein and hepatic vein $(\mathrm{g} /$ min), respectively and $C a, C p$ and $C h$ are the concentrations of metabolites in plasma $\left(\mathrm{NH}_{3}, \mathrm{nmol} / \mathrm{g}\right)$ or plasma water fraction (urea, estimated as plasma urea concentration/ (1-plasma DM fraction); nmol/g) in the aorta, portal vein and hepatic vein, respectively.

\section{Statistical analysis}

The data were initially analysed by ANOVA, as a crossover design, with animals as blocks and treatment $\left(\mathrm{NH}_{4} \mathrm{HCO}_{3}\right.$ administration) and period as factors. The effect of period was significant $(P<0.05)$ only for plasma urea concentration, $\mathrm{NH}_{3}$, urea and non- $\mathrm{NH}_{3}$ urea- $\mathrm{N}$ transfers across the liver and PDV release of valine. For all other data, this factor was removed and the data re-analysed by ANOVA with animals as blocks and treatment as the sole factor. Analyses were performed using the Genstat 5 (release 3.2) 
statistical package (Rothamstead Experimental Station, Herts., UK).

\section{Results}

\section{Animals, catheters and liver samples}

All animals completed the experiment and the catheters remained patent (i.e. allowed both blood collection and infusion of solutions), with the exception of one arterial catheter. In this animal, an additional polyvinyl chloride catheter was placed into the right ventricle via a jugular vein and, in both experimental periods, mixed venous heart blood was used for all determinations, except blood gas analysis. Comparative analyses of arterial and mixed right ventricle blood, performed later in two other animals, showed no significant differences between sampling sites in the concentration of urea and individual or total AAs (results not shown). Under basal conditions $(\mathrm{C} 0)$, the concentration of $\mathrm{NH}_{3}$ in the right ventricle blood was closer to that in the hepatic vein than to that in the artery. In practice, the small contribution of the hepatic artery to the total $\mathrm{NH}_{3}$ supply to the liver meant that the error introduced was $\leq 0.2$ and $\leq 2.0 \%$ total $\mathrm{NH}_{3}$ supply or removal for C0 and C1100, respectively.

The fresh liver weights of the two sheep killed were 630 and $653 \mathrm{~g}$, with fractional liver weights of 0.015 and $0 \cdot 017 \mathrm{~g} / \mathrm{kg}$ body weight, respectively.

\section{Acid-base parameters and blood flow}

Bicarbonate concentration increased in the aorta $(1.2 \mathrm{mM}$, $P=0.03)$, the hepatic $(2.6 \mathrm{~mm}, P=0.004)$ and the portal

Table 1. Blood flow, $\mathrm{pH}$ and blood variables in aorta and splanchnic vessels of four wethers infused with 0 (C0) or 1100 (C1100)

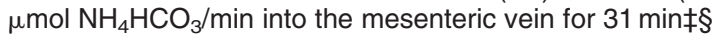

\begin{tabular}{|c|c|c|c|}
\hline & $\mathrm{CO}$ & C1100 & SED \\
\hline \multicolumn{4}{|l|}{ Blood flow (g/min) } \\
\hline Hepatic artery & 294 & 282 & $86 \cdot 0$ \\
\hline Portal vein & 1543 & 1465 & $186 \cdot 8$ \\
\hline \multirow{2}{*}{\multicolumn{4}{|c|}{$\mathrm{pH}$}} \\
\hline & & & \\
\hline Aorta\|\| & $7 \cdot 45$ & $7 \cdot 45$ & 0.004 \\
\hline Portal vein & $7 \cdot 37$ & $7 \cdot 40$ & $0.007^{*}$ \\
\hline Hepatic vein & $7 \cdot 38$ & $7 \cdot 38$ & 0.010 \\
\hline \multicolumn{4}{|l|}{$\mathrm{HCO}_{3}^{-}(\mathrm{mm})$} \\
\hline Aortal| & $24 \cdot 1$ & $25 \cdot 3$ & $0.11^{\text {** }}$ \\
\hline Portal vein & 23.9 & $26 \cdot 7$ & $0.31^{\star}$ \\
\hline Hepatic vein & 24.3 & $26 \cdot 8$ & $0.10^{* *}$ \\
\hline \multicolumn{4}{|l|}{$\mathrm{NH}_{3}(\mu \mathrm{M})$} \\
\hline Aorta & 83 & 308 & $79.8 \dagger$ \\
\hline Portal vein & 369 & 1334 & $119 \cdot 7^{\star \star}$ \\
\hline Hepatic vein & 79 & 472 & $95 \cdot 4^{*}$ \\
\hline \multicolumn{4}{|l|}{ Urea (mM) } \\
\hline Aortall & 4.56 & 5.58 & $0.138^{*}$ \\
\hline Portal vein\| & $4 \cdot 40$ & $5 \cdot 46$ & $0 \cdot 147^{*}$ \\
\hline Hepatic vein $\|$ & $4 \cdot 68$ & $5 \cdot 91$ & $0 \cdot 158^{\star}$ \\
\hline
\end{tabular}

† $P<0.1,{ }^{*} P<0.05,{ }^{* *} P<0.01$.

$\ddagger$ For details of procedures, see p. 508 .

$\S$ Analysed by ANOVA, with 3 d.f. for the residual mean square $(n 8)$.

\| Only 2 d.f. for the residual mean square.

I $n 6$. vein $(2.8 \mathrm{~mm}, P=0.03)$ during $\mathrm{NH}_{4} \mathrm{HCO}_{3}$ administration while $p \mathrm{CO}_{2}$ remain unchanged in all three sampling sites (Table 1). A small elevation in blood $\mathrm{pH}(0.02 \mathrm{pH}$ units, $P=0.055)$ was recorded in the portal vein. The blood flows in the portal and hepatic veins were not altered by the $\mathrm{NH}_{4} \mathrm{HCO}_{3}$ infusion and averaged 40.6 (SEM 3.6) and 48.4 (SEM 3.5 ) g/kg body weight per min, respectively. The hepatic artery contributed $16 \%$ of the total liver blood flow.

\section{Plasma urea and ammonia concentration}

Average plasma $\mathrm{NH}_{3}$ concentration increased in the portal $(P=0.004)$ and hepatic veins $(P=0.026)$ following $\mathrm{NH}_{4} \mathrm{HCO}_{3}$ infusion (Table 1). In the aorta, $\mathrm{NH}_{3}$ concentration increased progressively to $406 \mu \mathrm{M}$ (SEM $125 \mu \mathrm{M}$; Fig. 1) by the end of the $\mathrm{NH}_{4} \mathrm{HCO}_{3}$ infusion. This is approximately $50 \%$ of the value associated with severe $\mathrm{NH}_{3}$ toxicity in ruminant animals (Symonds et al. 1981); but the sheep showed none of the commonly reported clinical signs of $\mathrm{NH}_{3}$ toxicity (e.g. restlessness, respiratory distress or rapid respiratory movements; Symonds et al. 1981). Average plasma urea concentration was $1.0-1.2 \mathrm{~mm}$ higher $(P<0.02)$ in all three sampling sites during $\mathrm{NH}_{4} \mathrm{HCO}_{3}$ infusion.

\section{Urea and ammonia transfers}

Basal (C0) $\mathrm{NH}_{3}$ appearance across the PDV represented $0 \cdot 36$ of the apparent total $\mathrm{N}$ entering the gastrointestinal tract (i.e. $\mathrm{N}$ intake + urea-N uptake by the PDV, $1219 \mu \mathrm{mol}$ $\mathrm{N} / \mathrm{min}$ ) and 0.57 of the total $\mathrm{N}$ apparently absorbed by the gastrointestinal tract (Table 2). This was not significantly

Table 2. Mass flow of $\mathrm{NH}_{3}$ and urea to and from the liver and net mass transfer of $\mathrm{NH}_{3}$, urea, non- $\mathrm{NH}_{3}$ urea-N (NAUN) and free amino acid- $\mathrm{N}(\mu \mathrm{mol} / \mathrm{min})$ across the splanchnic tissues in four wethers infused with $0(\mathrm{C} 0)$ or $1100(\mathrm{C} 1100) \mu \mathrm{mol} \mathrm{NH}_{4} \mathrm{HCO}_{3} / \mathrm{min}$ into the mesenteric vein for $31 \mathrm{~min} \ddagger \S \|$

(Mean values with their standard errors for four wethers)

\begin{tabular}{lrrc}
\hline & C0 & C1100 & SED \\
\hline Portal-drained viscera & & & \\
$\mathrm{NH}_{3}$ & 435 & 1504 & $72 \cdot 9^{\star \star *}$ \\
Urea & -202 & -182 & $28 \cdot 6$ \\
Liver & & & \\
$\mathrm{NH}_{3}$ & 579 & 2008 & $160 \cdot 3^{\star *}$ \\
Inflow & 140 & 794 & $135 \cdot 8^{*}$ \\
Outflow & -439 & -1214 & $14 \cdot 8^{\star \star *}$ \\
Net transferף & & & \\
Urea & 7188 & 8602 & $586 \cdot 1 \dagger$ \\
Inflow & 7588 & 9279 & $636 \cdot 9 \dagger$ \\
Outflow & 401 & 677 & $1 \cdot 5^{\star \star *}$ \\
Net transferף & & & \\
NAUN & 362 & 140 & $14 \cdot 6^{\star *}$ \\
Net Transferq & & & \\
Free amino acid-N & -346 & -194 & $93 \cdot 4$ \\
Net transfer & & & \\
\hline
\end{tabular}

$\dagger P<0.1,{ }^{*} P<0.05,{ }^{* *} P<0.01,{ }^{* * *} P<0.001$.

$\ddagger$ For details of procedures, see p. 508 .

$\S$ For net transfers, the positive sign indicates net release, the negative, net uptake.

$\|$ Analysed by ANOVA, with 3 d.f. for the residual mean square ( $n$ 8).

1 Only 2 d.f. for the residual mean square. 


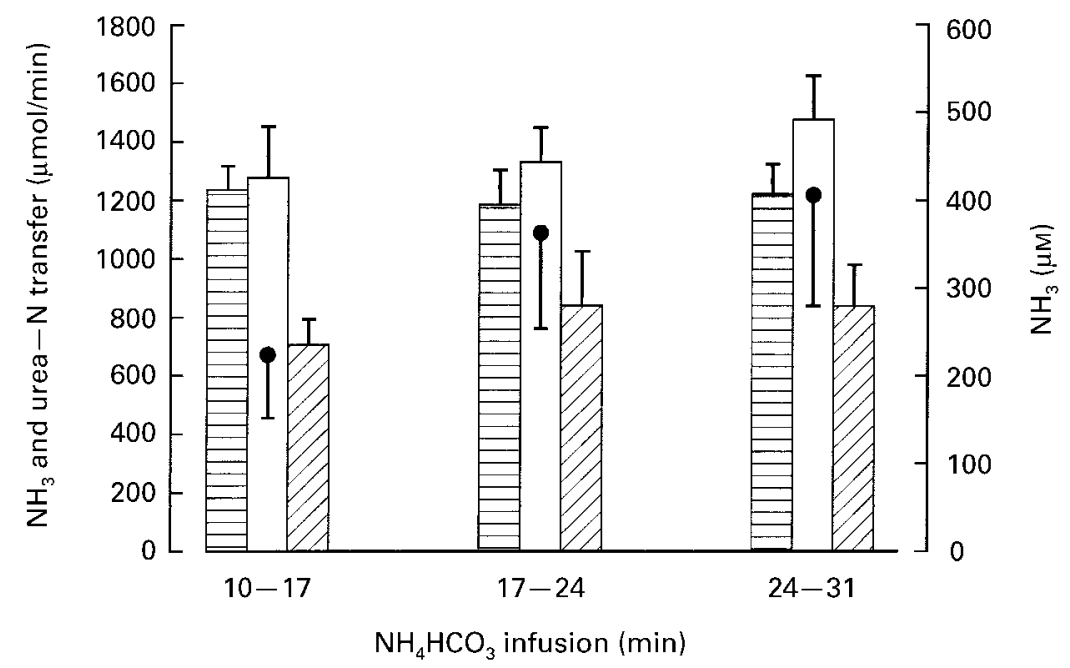

Fig. 1. Temporal changes in arterial ammonia concentration, hepatic ammonia removal, urea- $\mathrm{N}$ release and ammonia outflow during a short-term (31 min) infusion

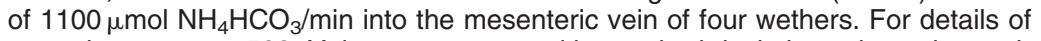
procedures, see p. 508. Values are means with standard deviations shown by verti-

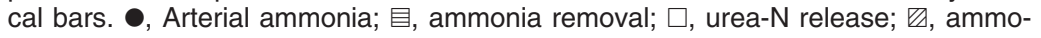
nia outflow.

Table 3. Net transfer of amino acids ( $\mu \mathrm{mol} / \mathrm{min}$ ) across the splanchnic tissues of four wethers infused with $0(\mathrm{CO})$ or $1100(\mathrm{C} 1100) \mu \mathrm{mol} \mathrm{NH}_{4} \mathrm{HCO}_{3} /$ min into the mesenteric vein for 31 min $\ddagger \S \|$

\begin{tabular}{|c|c|c|c|c|c|c|}
\hline & \multicolumn{3}{|c|}{ Portal-drained viscera } & \multicolumn{3}{|c|}{ Liver } \\
\hline & $\mathrm{CO}$ & C1100 & SED & $\mathrm{CO}$ & C1100 & SED \\
\hline Aspartic acid & $3 \cdot 8$ & 1.9 & $2 \cdot 3$ & -0.1 & $0 \cdot 6$ & 0.9 \\
\hline Threonine & $19 \cdot 5$ & $13 \cdot 3$ & $4 \cdot 6$ & -14.0 & $-9 \cdot 1$ & 3.0 \\
\hline Serine & $20 \cdot 4$ & $18 \cdot 9$ & $6 \cdot 0$ & -17.5 & $-14 \cdot 7$ & $7 \cdot 5$ \\
\hline Asparagine & $36 \cdot 7$ & $23 \cdot 8$ & $5.4 \dagger$ & $-22 \cdot 1$ & $-20 \cdot 9$ & $5 \cdot 3$ \\
\hline Glutamic acid & $6 \cdot 0$ & $1 \cdot 2$ & $3 \cdot 7$ & $9 \cdot 8$ & $21 \cdot 7$ & $3 \cdot 1^{*}$ \\
\hline Glutamine & -4.5 & $-8 \cdot 4$ & $12 \cdot 7$ & $-25 \cdot 3$ & $-10 \cdot 5$ & $12 \cdot 6$ \\
\hline Glycine & $35 \cdot 4$ & $31 \cdot 1$ & $17 \cdot 8$ & $-43 \cdot 6$ & $-40 \cdot 1$ & $12 \cdot 6$ \\
\hline Alanine & $44 \cdot 8$ & $34 \cdot 0$ & 5.9 & $-46 \cdot 4$ & $-32 \cdot 6$ & $15 \cdot 1$ \\
\hline Citrulline & $12 \cdot 3$ & $14 \cdot 4$ & $3 \cdot 3$ & $-9 \cdot 0$ & -0.9 & $3.4 \dagger$ \\
\hline Valineף & $22 \cdot 2$ & $6 \cdot 2$ & $2 \cdot 2^{\star}$ & $-10 \cdot 2$ & $0 \cdot 1$ & $6 \cdot 4$ \\
\hline Methionine & $6 \cdot 2$ & 4.3 & 1.0 & -4.9 & -2.9 & 0.9 \\
\hline Isoleucine & $20 \cdot 5$ & $11 \cdot 6$ & $3.6 \dagger$ & $-1 \cdot 7$ & 0.7 & 4.5 \\
\hline Leucine & $29 \cdot 0$ & $15 \cdot 7$ & $4.8 \dagger$ & $-3 \cdot 0$ & $-1 \cdot 3$ & $3 \cdot 4$ \\
\hline Tyrosine & $14 \cdot 3$ & $8 \cdot 6$ & 2.9 & $-10 \cdot 9$ & $-8 \cdot 0$ & $3 \cdot 0$ \\
\hline Phenylalanine & $17 \cdot 5$ & $12 \cdot 0$ & 4.3 & $-15 \cdot 2$ & -14.5 & $2 \cdot 3$ \\
\hline Ornithine & $6 \cdot 2$ & $6 \cdot 0$ & 1.9 & $7 \cdot 1$ & $-5 \cdot 4$ & $1 \cdot 3^{\star \star \star}$ \\
\hline Lysine & $17 \cdot 8$ & $12 \cdot 7$ & $2 \cdot 8$ & $-7 \cdot 7$ & $-2 \cdot 6$ & $1 \cdot 1^{*}$ \\
\hline 1-methylhistidine & -3.6 & $-1 \cdot 0$ & 1.6 & 0.0 & 4.4 & $2 \cdot 7$ \\
\hline Histidine & $5 \cdot 8$ & $4 \cdot 1$ & $1 \cdot 6$ & $-5 \cdot 6$ & $-6 \cdot 0$ & 1.7 \\
\hline 3-methylhistidine & -0.5 & -0.3 & 1.2 & -0.5 & 1.5 & $2 \cdot 0$ \\
\hline Arginine & $10 \cdot 5$ & $6 \cdot 0$ & $6 \cdot 4$ & $-12 \cdot 1$ & 1.4 & $5 \cdot 2 \dagger$ \\
\hline Total AA & 324.5 & $217 \cdot 3$ & $72 \cdot 6$ & $-232 \cdot 6$ & $-145 \cdot 0$ & $65 \cdot 4$ \\
\hline Essential AA & 138.5 & $79 \cdot 9$ & $23.8 \dagger$ & $-62 \cdot 4$ & $-35 \cdot 5$ & $15 \cdot 8$ \\
\hline Branched-chain AA & $71 \cdot 7$ & 33.5 & $11 \cdot 4^{*}$ & -14.9 & -0.5 & $11 \cdot 2$ \\
\hline Non-essential AA & $167 \cdot 6$ & $117 \cdot 0$ & $47 \cdot 1$ & $-168 \cdot 3$ & $-103 \cdot 1$ & $51 \cdot 0$ \\
\hline Glucogenic AA & $96 \cdot 1$ & $75 \cdot 6$ & $34 \cdot 7$ & $-132 \cdot 9$ & $-98 \cdot 0$ & $43 \cdot 3$ \\
\hline
\end{tabular}

AA, amino acids.

$\dagger P<0.1,{ }^{*} P<0.05,{ }^{* *} P<0.01,{ }^{* * *} P<0.001$.

$\ddagger$ For details of procedures, see p. 508 .

$\S$ The positive sign indicates net release, the negative, net uptake.

$\|$ Analysed by ANOVA, with 3 d.f. for the residual mean square $(n 8)$.

I) Only 2 d.f. for the residual mean square. 
different from urea-N removal by the PDV (435 $v$. $404 \mu \mathrm{mol} / \mathrm{N}$ min; $P>0 \cdot 2)$. PDV transfer of $\mathrm{NH}_{3}$, but not urea, increased by $1069 \mu \mathrm{mol} / \mathrm{min}(P<0.001)$ during the $\mathrm{NH}_{4} \mathrm{HCO}_{3}$ infusion, similar to the average infusion rate $(1180 \mu \mathrm{mol} \mathrm{N} / \mathrm{min})$, indicating that the basal rate of $\mathrm{NH}_{3}$ appearance across the PDV was not altered by the infusion.

Liver inflow, outflow and removal of $\mathrm{NH}_{3}$ were all increased by the $\mathrm{NH}_{4} \mathrm{HCO}_{3}$ infusion. The average $\mathrm{NH}_{3}$ input to the liver in $\mathrm{C} 1100$ exceeded the maximum capacity for hepatic removal of $\mathrm{NH}_{3}$ by $654 \mu \mathrm{mol} / \mathrm{min}$, so that $\mathrm{NH}_{3}$ exited the liver at a rate 5.7 times higher than that measured in $\mathrm{C} 0$. Based on an average liver weight of $642 \mathrm{~g}$, the hepatic $\mathrm{NH}_{3}$ removal during $\mathrm{NH}_{4} \mathrm{HCO}_{3}$ infusion was $1.90 \mu \mathrm{mol} /$ min per $\mathrm{g}$ wet liver weight (see Table 2).

Hepatic urea-N release was 1.9 times higher than $\mathrm{NH}_{3}$ uptake under basal (C0) conditions and increased to $1354 \mu \mathrm{mol} / \mathrm{min}$ in $\mathrm{C} 1100(P<0 \cdot 001)$, sufficient to account for hepatic $\mathrm{NH}_{3}$ removal. When the data were compared on an incremental basis (i.e. $\mathrm{C} 1100-\mathrm{C} 0$ ), urea-N release was on average only 0.71 of the $\mathrm{NH}_{3}$ removal, resulting in an apparent net decrease in the calculated non- $\mathrm{NH}_{3}-\mathrm{N}$ appearing as urea-N $(P=0 \cdot 004$; Table 2$)$. The time course of $\mathrm{NH}_{3}$ and urea transfers during $\mathrm{NH}_{4} \mathrm{HCO}_{3}$ infusion (Fig. 1) showed, however, that while hepatic $\mathrm{NH}_{3}$ extraction remained unaltered for the $21 \mathrm{~min}$ sampling period (slope $-1.06 \mu \mathrm{mol} / \mathrm{min}$ per $\mathrm{min}$ (SE of the slope 4.879 ), $P=0.83$, residual mean square $9333 \cdot 14$ ), urea- $\mathrm{N}$ release by the liver increased progressively from 1278 to $1474 \mu \mathrm{mol} / \mathrm{min}$ (slope $14.06 \mu \mathrm{mol} / \mathrm{min}$ per $\mathrm{min}$ (SE of the slope $7 \cdot 22$ ), $P=0.07$, residual mean square 20437.6). Thus, the additional urea-N release: additional $\mathrm{NH}_{3}-\mathrm{N}$ removal ratio increased from 0.52 to 0.90 over the same period.

\section{Plasma amino acid concentrations}

Arterial, portal and hepatic vein plasma concentrations of free total AA (aorta $2625 \mu \mathrm{M}$ (SEM 99.5)), essential AA (aorta $986 \mu \mathrm{M}$ (SEM 53.0)), non-essential AA (aorta $1351 \mu \mathrm{M}$ (SEM 42.6)), branched-chain AA (aorta $566 \mu \mathrm{M}$ (SEM 36.5)) and glucogenic AA (aorta $927 \mu \mathrm{M}$ (SEM 34.8)) were not altered by the $\mathrm{NH}_{4} \mathrm{HCO}_{3}$ infusion. Glutamine concentration was higher in the aorta (222 v. $308 \mu \mathrm{M}$ (SED 18.6), $P=0.02)$, the portal (221 v. $302 \mu \mathrm{M}$ (SED 11.8), $P=$ $0 \cdot 01)$ and the hepatic (199 v. $292 \mu \mathrm{M}(\operatorname{SED} 17 \cdot 3), P=0.02)$ veins and a similar, though smaller, response was apparent for aspartate (aorta 7 v. $10 \mu \mathrm{M}$ (SED 0.8), $P<0.05$ ). In contrast, ornithine concentration was consistently decreased at all sites (aorta 102 v. $70 \mu \mathrm{M}(\mathrm{SED} 7 \cdot 3$ ), $P=0.02$; portal vein $108 v .76 \mu \mathrm{M}(\operatorname{SED} 8.0), P=0.03$; hepatic vein $112 v$. $71 \mu \mathrm{M}$ (SED 8.6), $P=0 \cdot 02$ ) in C1100. Lower concentrations were also observed for alanine (200 v. $173 \mu \mathrm{M}$ (SED 7.4), $P=0 \cdot 04)$, tyrosine (104 v. $98 \mu \mathrm{M}$ (SED $2 \cdot 0), P=0 \cdot 05)$ and phenylalanine in the portal vein (86 v. $74 \mu \mathrm{M}$ (SED 3.1), $P=0.03$ ), with similar trends for threonine in both the aorta (86 v. $74 \mu \mathrm{M}(\operatorname{SED} 3 \cdot 1), P=0 \cdot 08)$ and the portal vein (194 $v$. $168 \mu \mathrm{M}$ (SED 9.3), $P=0 \cdot 07)$ and alanine in the aorta (158 $v$. $140 \mu \mathrm{M}(\operatorname{SED} 7 \cdot 9), P=0 \cdot 1)$.

\section{Amino acid transfers}

With the exception of glutamine, which was removed by the gastrointestinal tissues, a net absorption of all other AAs was measured across the PDV in $\mathrm{C} 0$, with essential AA representing 0.43 of total AA transfers. The net release of free total AA, non-essential AA and glucogenic AA across the PDV was not modified by $\mathrm{NH}_{4} \mathrm{HCO}_{3}$ infusion. The reduction in net PDV release of valine $(P=0.018)$ and the trend for decreased net PDV release of isoleucine $(P=0.09)$ and leucine $(P=0 \cdot 07)$, resulted in significantly reduced total branched-chain AA transfers $(P=0.04)$ and in a trend for lower free essential AA transfers across the PDV $(P=0.09)$ in $\mathrm{C} 1100$ (see Table 3).

Under basal conditions, the liver removed $0 \cdot 71,0 \cdot 45,0 \cdot 21$ and all of the free total AA, essential AA, branched-chain AA and non-essential AA respectively, absorbed across the PDV. The free glucogenic AA were extracted at a rate 1.4 times greater than the PDV appearance, while net hepatic release was observed for glutamate and ornithine. The $\mathrm{NH}_{4} \mathrm{HCO}_{3}$ infusion reduced total AA-N extraction by $152 \mu \mathrm{mol} / \mathrm{min}$, a decrease similar to the average reduction in non- $\mathrm{NH}_{3}$ urea-N release $(222 \mu \mathrm{mol} / \mathrm{min}$ (SED 63), $P=$ 0.59 ; Table 2). Glutamate release $(P=0.03)$ was significantly augmented, ornithine switched from net release to net removal $(P<0.001)$ and there was a reduction in lysine extraction $(P=0.02$; Table 3$)$.

Splanchnic bed release of valine $(12 v .6 \mu \mathrm{mol} / \mathrm{min}$ (SED $22 \cdot 4), P=0 \cdot 09$ ), isoleucine (19 v. $12 \mu \mathrm{mol} / \mathrm{min}$ (SED 2.3), $P=0.07$ ), leucine (26v. $14 \mu \mathrm{mol} / \mathrm{min}$ (SED 1.4), $P<0.01)$, and tyrosine ( 4 v. $1 \mu \mathrm{mol} / \mathrm{min}$ (SED 0.7$), P=0.03$ ) were reduced during $\mathrm{NH}_{4} \mathrm{HCO}_{3}$ infusion. This meant that the net appearance of free branched-chain AA (57v. $33 \mu \mathrm{mol} / \mathrm{min}$ (SED 2.0), $P=0.001)$ and essential AA (76 v. $44 \mu \mathrm{mol} / \mathrm{min}$ (SED 9.2), $P=0.04$ ) across the splanchnic tissues during C1100 dropped to 0.58 of that under basal conditions. In addition, the splanchnic tissues released more citrulline (3v. $14 \mu \mathrm{mol} / \mathrm{min}(\operatorname{SED} 1.7), P=0.01)$ and arginine $(-2 v$. $7 \mu \mathrm{mol} / \mathrm{min}$ (SED 2.4), $P=0.04$ ), but almost no ornithine (13 v. $1 \mu \mathrm{mol} / \mathrm{min}$ (SED $1 \cdot 3), P<0 \cdot 01$ ), to the peripheral circulation.

\section{Discussion}

Short-term adaptation of glutamate dehydrogenase activity v. amino acid degradation: how to balance citrulline synthesis in the ornithine cycle

Experiments with ${ }^{15} \mathrm{NH}_{4} \mathrm{Cl}$ in vitro (Lomax et al. 1995; Luo et al. 1995) and in vivo (Milano et al. 1995) have offered unequivocal evidence that $\mathrm{NH}_{3}-\mathrm{N}$ can provide both $\mathrm{N}$ atoms of urea during hepatic ureagenesis in sheep. Moreover, in recent studies in sheep with chronic $(4 \mathrm{~d})$ infusion of $\mathrm{NH}_{4} \mathrm{HCO}_{3}$ into the mesenteric vein, all additional $\mathrm{NH}_{3}-\mathrm{N}$ removed by the liver was converted into urea without the need for substantial inputs of AA-N (i.e. the additional urea-N released: additional $\mathrm{NH}_{3}-\mathrm{N}$ removed ratio by the liver ranged from $0 \cdot 9$ to 1.1; Lobley et al. 1996; Milano et al. 2000). Overall, these observations indicate that under conditions of sustained, high portal $\mathrm{NH}_{3}$ flows, hepatic glutamate dehydrogenase activity and related pathways that supply 2-oxoglutarate and $\mathrm{NADH}$ can adjust to allow partition of the extra portal $\mathrm{NH}_{3}$ removed equally between glutamate dehydrogenase and carbamoyl-phosphate 
synthase 1-ornithine transcarbamylase routes, without compromising amino acid-N to balance $\mathrm{N}$ inputs to the urea cycle.

In earlier studies, however, where ammonium salts were infused for 2 or $3 \mathrm{~h}$ into the mesenteric vein of sheep (Barej et al. 1987; Orzechowsky et al. 1988) and cattle (Symonds et al. 1981; Wilton et al. 1988) the additional urea- $\mathrm{N}$ released by the liver exceeded the additional $\mathrm{NH}_{3}$ removed by more than two-fold. Thus, in the short term, stimulation of glutamate production from $\mathrm{NH}_{3}$ and oxo-glutarate through glutamate dehydrogenase appeared to be limited, and additional aspartate- $\mathrm{N}$ from catabolic deamination of AAs was needed to balance $\mathrm{NH}_{3}$ flow through the carbamoyl-phosphate synthase 1ornithine transcarbamylase route.

The current observations challenge this view. Although the maximum hepatic capacity for $\mathrm{NH}_{3}$ removal was exceeded by over $650 \mu \mathrm{mol} / \mathrm{min}$ during the $\mathrm{NH}_{4} \mathrm{HCO}_{3}$ infusion, with hyperammonaemia established within $10 \mathrm{~min}$, there was no apparent need for additional AA-N inputs to maintain $\mathrm{NH}_{3}$-stimulated ureagenesis. Moreover, rather than the over-production of urea-N relative to $\mathrm{NH}_{3}$ extraction reported by others, here the average underconversion of $222 \mu \mathrm{mol} \mathrm{N} / \mathrm{min}$ to urea $(P=0.004)$ and the reduction in lysine removal $(-5 \cdot 1 \mu \mathrm{mol} / \mathrm{min}$, $P=0.02$ ) provide support for the concept that shortterm inhibition of AA oxidation may occur during $\mathrm{NH}_{3}$ overload. Interestingly, this is contrary to the proposal that $\mathrm{NH}_{3}$ detoxification leads to elevated catabolism of AAs (Reynolds, 1992; Parker et al. 1995). The reduction in non$\mathrm{NH}_{3}$ urea-N release by the liver could also indicate that the unaccounted $\mathrm{N}$ may be used for synthesis of AAs. Studies in vitro and in vivo have shown that rapid and substantial transfer of ${ }^{15} \mathrm{~N}$ from ${ }^{15} \mathrm{NH}_{4}^{+}$to AAs can occur within the liver (Geissler et al. 1992; Luo et al. 1995). In addition, incubation of hepatocytes or liver perfusion with $\mathrm{NH}_{4} \mathrm{Cl}$ resulted in intracellular accumulation of citrulline, aspartate, glutamate, glycine, serine and alanine (Demigne et al. 1991; Nissim et al. 1992) or increased release of glutamate, citrulline and alanine (Nissim et al. 1992; Luo et al. 1995; Brosnan et al. 1996). The elevated net release of glutamate and lowered net removal of citrulline across the liver in the current study provide confirmatory evidence in vivo of the potential importance of these mechanisms in reponse to acute $\mathrm{NH}_{3}$ administration.

Care was taken in the present study to avoid stimulation of AA catabolism associated with acidosis, as encountered with use of $\mathrm{NH}_{4} \mathrm{Cl}$ (Reaich et al. 1992; Lobley et al. 1995); this precaution may account for the differences observed between the current study and earlier studies conducted by Barej et al. (1987) and Orzechowsky et al. (1988).

\section{Time course events}

The stability of hepatic $\mathrm{NH}_{3}$ utilisation together with the progressive increase in urea- $\mathrm{N}$ synthesis observed during maximal stimulation with $\mathrm{NH}_{3}$ have two important consequences. First, the convergence of incremental $\mathrm{NH}_{3}$ removal and urea- $\mathrm{N}$ release towards the end of the infusion minimised the apparent reduction in non- $\mathrm{NH}_{3}$ urea-N release, suggesting that any conservation of AAs is only a transient response. Second, any factors that initially limited $\mathrm{N}$ flux through the ornithine cycle must have been subjected to short-term control.

The activity of carbamoyl-phosphate synthase 1, the rate-limiting enzyme of the cycle and known to be insensitive to product inhibition by carbamoyl phosphate (Meijer et al. 1990), was probably not altered, because that would have increased hepatic $\mathrm{NH}_{3}$ removal over the infusion period. Under the experimental conditions created by the infusion (i.e. steady $\mathrm{NH}_{3}$ removal and increase in average hepatic glutamate release), however, stimulation of carbamoyl-phosphate synthase 1 activity may have occurred through a progressive transfer of $\mathrm{NH}_{3}-\mathrm{N}$ from glutamate to carbamoyl phosphate synthesis.

Ornithine availability has been shown to limit rates of urea synthesis in isolated hepatocytes (Lund \& Wiggins, 1986). In the present experiment, the marked shift from release to uptake recorded for hepatic ornithine transfers ( $7 \cdot 1$ v. $-5.4 \mu \mathrm{mol} / \mathrm{min}, P<0.001)$, and the depletion of ornithine plasma concentrations $(P<0.05)$ indicate that the liver demand for this metabolite increased substantially during $\mathrm{NH}_{4} \mathrm{HCO}_{3}$ infusion. Whether hepatic ornithine concentration rose in parallel to these transfers is unclear, as there was also reduced net uptake of two products, citrulline and arginine.

\section{Amino acid metabolism}

Time course analysis highlighted the importance of hepatic $\mathrm{NH}_{3}$ removal for maintaining $\mathrm{NH}_{3}$ homeostasis in ruminant animals. The two major mechanisms for $\mathrm{NH}_{3}$ detoxication, ureagenesis and glutamine synthesis, are highly compartmentalised in the liver acinus, the ornithine cycle enzymes being expressed in periportal hepatocytes and glutamine synthetase in perivenous cells (Haussinger et al. 1992; Rossouw et al. 1999). Thus, any overflow of $\mathrm{NH}_{3}$ that escapes periportal ureagenesis stimulates perivenous glutamine synthesis. In the current study, however, although ureagenic capacity was exceeded, the liver remained a net consumer (albeit at a lesser rate) of glutamine during $\mathrm{NH}_{3}$ overload. Nonetheless, plasma concentrations of glutamine were substantially increased during $\mathrm{NH}_{3}$ infusion, suggesting that glutamine synthesis may be stimulated in other tissues. Indeed, Leweling et al. (1996) reported an increase in plasma and muscle glutamine concentrations during hyperammonaemia in rats. This was accompanied by a decline in glutamate, alanine and branched-chain AA concentrations in both compartments. The authors hypothesised that enhanced branched-chain AA degradation occurred to restore the intramuscular glutamate pools, depleted during the synthesis of glutamine induced by hyperammonaemia. Although arterial plasma alanine and glutamate concentrations tended to decrease during the infusion of $\mathrm{NH}_{4} \mathrm{HCO}_{3}$ in the current study, there were no changes in arterial branched-chain AA concentrations. Instead, branched-chain AA utilisation by the PDV was enhanced, suggesting mechanisms in addition to muscle degradation of branched-chain AA to provide glutamate $\mathrm{C}$ or $\mathrm{N}$ may contribute to lower arterial branched-chain AA concentrations during hepatic $\mathrm{NH}_{3}$ overload. 


\section{Concluding remarks}

The results of this experiment indicate that it is unlikely that, in the short term, maximal rates of liver $\mathrm{NH}_{3}$ removal will stimulate AA utilisation to balance $\mathrm{NH}_{3}$ incorporation to urea synthesis. Moreover, maximal rates of $\mathrm{NH}_{3}$ removal were reached at least $20 \mathrm{~min}$ earlier than approximately equivalent rates of urea synthesis, with a significant increase in hepatic removal of ornithine and decrease in plasma ornithine concentration. Thus, in sheep, short-term adaptation of hepatic urea synthesis to $\mathrm{NH}_{3}$ overload in vivo might be controlled by ornithine availability to liver cells. $\mathrm{NH}_{3}$ supply in excess to liver removal resulted in higher arterial concentrations of $\mathrm{NH}_{3}$ and glutamine but did not alter glutamine release by the liver. Instead, hepatic release of glutamate increased and there was a marked reduction in liver removal of lysine and splanchnic release of tyrosine and branched-chain AA.

\section{Acknowledgements}

This work was funded, in part, by the Scottish Environmental and Rural Affairs Department from the core budget to the Rowett Research Institute. GDM was sponsored by the Facultad de Ciencias Veterinarias (Universidad Nacional del Centro, UNCPBA, Tandil, Argentina), the Consejo Nacional de Investigaciones Científicas y Técnicas (CONICET, Argentina), the Fundación Antorchas (Argentina) and The British Council. The expert analytical skills of Miss M. Annand and Mr A.G. Calder are gratefully acknowledged.

\section{References}

Barej W, Ostaszewski P \& Pierzynowski G (1987) Urea and glucose formation in ovine liver after ammonia and lactate loading in vivo. Annales de Recherches Veterinaires 18, 29-34.

Brosnan JT, Brosnan ME, Charron R \& Nissim I (1996) A mass isotopomer study of urea and glutamine synthesis from ${ }^{15} \mathrm{~N}$-labelled ammonia in the perfused rat liver. Journal of Biological Chemistry 271, 16199-16207.

Demigné C, Yacoub C, Morand C \& Rémésy C (1991) Interactions between propionate and amino acid metabolism in isolated sheep hepatocytes. British Journal of Nutrition 65, 301-317.

Geissler A, Kanamori K \& Ross BD (1992) Real-time study of urea cycle using ${ }^{15} \mathrm{~N}$ n.m.r. in the isolated perfused liver. Biochemical Journal 287, 813-820.

Häussinger D, Lamers WH \& Moorman AFM (1992) Hepatocyte heterogeneity in the metabolism of amino acids and ammonia. Enzyme 46, 72-93.

Leweling H, Breitkreutz R, Behne F, Staedt U \& Striebel JP (1996) Hyperammonaemia-induced depletion of glutamate and branched-chain amino-acids in muscle and plasma. Journal of Hepatology 25, 756-762.

Lobley GE, Connell A, Lomax MA, Brown DS, Milne E, Calder AG \& Farningham DAH (1995) Hepatic detoxification of ammonia in the ovine liver: possible consequences for amino acid catabolism. British Journal of Nutrition 73, 667-685.
Lobley GE, Weijs PJM, Connell A, Calder AG, Brown DS \& Milne E (1996) The fate of absorbed and exogenous ammonia as influenced by forage or forage-concentrate diets in growing sheep. British Journal of Nutrition 76, 231-248.

Lomax MA, Maltby SA, Buss DS \& Lobley GE (1995) Regulation of ammonia and amino acid metabolism in isolated sheep hepatocytes. Proceedings of the Nutrition Society 55, 39A.

Lund P \& Wiggins D (1986) The ornithine requirement of urea synthesis. Formation of ornithine from glutamine in hepatocytes. Biochemical Journal 239, 773-776.

Luo QJ, Maltby SA, Lobley GE, Calder AG \& Lomax MA (1995) The effect of amino acids on the metabolic fate of ${ }^{15} \mathrm{NH}_{4} \mathrm{Cl}$ in isolated sheep hepatocytes. European Journal of Biochemistry 228, 912-917.

Meijer AJ, Lamers WH \& Chalumeau RAFN (1990) Nitrogen metabolism and ornithine cycle function. Physiological Reviews 70, 701-748.

Milano GD, Hotston-Moore A \& Lobley GE (2000) Influence of hepatic $\mathrm{NH}_{3}$ removal on ureagenesis, amino acid utilisation and energy metabolism in the ovine liver. British Journal of Nutrition 83, 307-315.

Milano GD, Lomax MA \& Lobley GE (1995) Estimation of the enrichment of urea $\mathrm{N}$ precursors. Proceedings of the Nutrition Society 55, 42A.

Mondzac A, Erlich GE \& Seegmiller JE (1965) An enzymatic determination of ammonia in biological fluids. Journal of Laboratory and Clinical Medicine 66, 526-531.

Nieto R, Calder AG, Anderson SE \& Lobley GE (1996) Method for the determination of ${ }^{15} \mathrm{NH}_{3}$ enrichment in biological samples by Gas Chromatography/Electron Impact Ionization Mass Spectrometry. Journal of Mass Spectrometry 31, 289-294.

Nissim I, Cattano C, Nissim I \& Yudkoff M (1992) Relative role of the glutaminase, glutamate dehydrogenase, and AMPdeaminase pathways in hepatic ureagenesis: Studies with ${ }^{15} \mathrm{~N}$. Archives of Biochemistry and Biophysics 292, 393-401.

Orzechowsky A, Pierzynowski S, Motyl T \& Barej W (1988) Net hepatic metabolism of ammonia, propionate and lactate in sheep in relation to gluconeogenesis and ureagenesis. Journal of Animal Physiology and Animal Nutrition 59, 113-122.

Parker DS, Lomax MA, Seal CJ \& Wilton JC (1995) Metabolic implications of ammonia production in the ruminant. Proceedings of the Nutrition Society 54, 549-563.

Reaich D, Channon SM, Scrimgeour CM \& Goodship THJ (1992) Ammonium chloride-induced acidosis increases protein breakdown and amino acid oxidation in humans. American Journal of Physiology 263, E735-E739.

Reynolds CK (1992) Metabolism of nitrogenous compounds by the ruminant liver. Journal of Nutrition 122, 850-854.

Rossouw HC, Nell MJ, Mohamed Ali A \& van der Walt JG (1999) Ammonia partitioning between urea and glutamine in the perfused sheep liver: role of extracellular pH. South African Journal of Animal Science 29, 246-247.

Stryer L (1988) Biochemistry, New York, NY: W.H. Freeman \& Company.

Symonds HW, Mather DL \& Collis KA (1981) The maximum capacity of the liver of the adult dairy cow to metabolize ammonia. British Journal of Nutrition 46, 481-486.

Wilton JC, Gill M \& Lomax MA (1988) Uptake of ammonia across the liver of forage-fed cattle. Proceedings of the Nutrition Society 47, 153A. 